\title{
Clare Wilson
}

ULSTER UNIVERSITY

\section{From the Inside Out: An Analytical Perspective of André Caplet's Harmonic Evolution Through Selected Mélodies,} 1915-1925

André Caplet's legacy is modest. He was not a prolific composer and a significant body of his compositional output is not widely known today. Upon closer consideration of Caplet's place in musical society, however, a portrait of an artist both respected by his contemporaries and in possession of a progressive attitude towards modern music begins to emerge. Through his modest legacy of works, Caplet's compositional language exhibits an extensive exploration to the boundaries of tonal language, and it is into this language that he infuses a richness of modality and chromaticism.

Detailed analytical exploration on the music of Caplet is still in its infancy and past research focusing specifically on Caplet is not abundant. Significant works considering Caplet's place in historical and musicological contexts include Denis Huneau's ${ }^{1}$ valuable project in two volumes cataloging Caplet's opus, informative articles such as

1 D. Huneau, André Caplet (1878-1925) Debussyste indépendant, Weinsberg 2007. 
those published by Williametta Spencer ${ }^{2}$ and Lucien Durosoir ${ }^{3}$ and a small number of theses. Most recently, in 2015, a dissertation entitled The Mélodies of André Caplet: A Guide to Performance was published by Joel Harder. Although not focused on rigorous analysis, this work includes suggestions on programming and recital detailing beneficial to musicians performing the mélodies. As Harder states,

\section{the overall purpose of the dissertation is to provide song enthusiasts and per- forming musicians alike detailed information... in the hope that his [Caplet's] music may appear more frequently in concert halls. ${ }^{4}$}

This article strives to build on past research by offering an analytical perspective on three aspects of Caplet's harmonic language as it developed during the years of the Great War and beyond. The chosen examples demonstrate an analytically and poetically informed exploration of the following areas of Caplet's evolving modal practice: modal juxtaposition and connectivity, the use of the acoustic scale, and mixing of synthetic scale structure with standard modal practice. Détresse (Distress), composed in 1915, Fôret (Forest), composed in 1917, are examples from the mélodie genre, and Écoute (Listen), composed in 1924 , is a small-scale work for flute and voice. To properly contextualise these pieces, a brief biographical sketch follows.

Caplet's formal musical education began at a young age under the tutelage of Henri Woollett in Le Havre. Upon entering the Paris Conservatoire at the age of eighteen, Caplet's striking musical aptitude was nourished and in 1901 he won the Prix du Rome. This success had a positive impact on furthering the young composer's musical development, affording him the opportunity to reside in the creative environment of the Villa de Medici, Italy. Caplet used this time to produce some early mélodies, but also travelled further afield to Germany, where he attended performances by famous conductors Mottl and Nikish in

2 See: W. Spencer, The Relationship between André Caplet and Claude Debussy, "The Musical Quarterly” 1980, 66 (1); W. Spencer, André Caplet, Aussi Musicien Français, "Revue Bege de Musicologie" 1982-84, 36 (38); W. Spencer, The melodies of André Caplet, "Journal of National Association of Teachers of Singing" 1984, 40 (4).

3 See in: F. de Maindreville, S. Etcharry, La Grande Guerre en musique: vie et creation musicales en France pendant la Première Guerre mondiale, Bruxelles 2014.

4 J. Harder, The Mélodies of André Caplet: A Guide to Performance, DMA Thesis, The Juilliard School, 2015, p. xii. 
Berlin. Upon making the decision to return to France early, Caplet arrived back in Paris to participate fully in musical life there. He became involved with the group Les Apaches alongside Ricardo Viñes, Manuel de Falla, Maurice Ravel and Paul Sourdes and gained recognition on several different levels: as a conductor, an orchestrator, and composer.

Caplet soon became acquainted with Debussy. The precise date of their introduction is unclear, but it most likely occurred between 1907 and 1908 through a letter by the poet and music critic Georges Jean-Aubry. Debussy was impressed by Caplet's talent, and a friendship and professional collaboration blossomed. It was after 1908 that Caplet soon became an assistant to Debussy. As Williametta Spencer outlines:

\footnotetext{
Often during this time, Debussy's poor health did not allow him to complete his work, and Caplet assisted in correcting proofs from the publishers, making transcriptions, and completing the orchestration for Gigues and Le Martyre de Saint Sebastien. Caplet also orchestrated the Children's Corner suite and Pagodes, and finished the orchestration of La Boite a joujoux, and reorchestrated Le Jet d'eau. ${ }^{5}$
}

The relationship between Caplet and Debussy lasted until Debussy's death in 1918, and thanks to the prolific nature of Debussy's letter writing, there is evidence that the two artists corresponded regularly throughout the war.

Caplet's active involvement in music making was extensive. The Société Musicale Independent (SMI) championed his work through several concerts. Nancy Toff describes:

\footnotetext{
The second concert, on March 9, devoted exclusively to the woks of the rising star André Caplet: the Quintet for piano and winds; the premiere of Suite Persane, a three-movement work on Perisan themes for double quintet; and the premiere of the complete Feuillets d'album, a set of five pieces for flute and piano, with the composer at the keyboard. ${ }^{6}$
}

The SMI further premiered Septuor for string quartet and three female voices in 1910, and the vocal work Le Pain Quotidian in 1922. Caplet's involvement with these groups, and his advocacy of new music,

5 W. Spencer, The Relationship..., op. cit., p. 112.

6 N. Toff, Monarch of the Flute, Oxford 2005, p. 59. 
significantly demonstrates his penchant for contemporary and new musical advancements. In addition, Caplet held the conductor's baton at the French premiere of Schoenberg's Five Orchestral Pieces in 1922. This premiere was controversial. The modern sound of Schoenberg's music elicited a response of turbulent proportions that led to policemen on horseback being dispatched to control the crowd. Reactions such as this did not deter Caplet's involvement in promoting modern music, or even his associations with the progressive SMI. Webern, speaking of the SMI, in a letter to Ravel dated 1927, mentions:

\section{Such an international embrace of new works signifies the SMI's high standards for compositional excellence, where a composer's worth is based not on nation- ality but on style, aesthetic, and quality. This truth grants composers the reward- ing knowledge that should their works be selected by the SMI, it is because their craft is deemed valuable, not because their piece fulfills a national stereotype. ${ }^{7}$}

Caplet was certainly at the centre of musical affairs in Paris, where he "shared the values of this generation, and projected these in his activities as an internationally acclaimed conductor." 8 During his role of principal conductor of the Boston Opera between 1910 and 1914, Caplet was a driving force in the introduction of his native music abroad. As Spencer states, "he lost no opportunity of directing the works of Debussy as soon as he began to conduct in America." Perhaps the demands of musical life in Boston explain the lack of substantial compositions by Caplet from this period and furthermore his magnetism as a conductor perhaps contributed to his popularity there. Denis Huneau mentions:

For all witnesses, Caplet exerts a fascination both on the orchestra and on the public who listen, he possesses a veritable aura. ${ }^{10}$

7 See: [online] http://musicalgeography.org/fictional-letter-societe-musicale-independante/ [accessed: 03.10.2016].

8 B. L. Kelly, Music and Ultra Modernism in France: A Fragile Consensus, 1913-1939, Woodbridge 2013, p. 194.

9 W. Spencer, André Caplet..., op. cit., p. 171.

10 D. Huneau, op. cit., p. 283: "Pour les témoins, Caplet exerce une fascination à la fois sur l'orchestre et sur le public qui l'écoute, il possède une veritable aura." 
The war years saw an increase in composition, however, as there is a significant body of mélodies surviving from Caplet's time at the front. Caplet composed melodies inspired by his personal response to the war, but also perhaps for other strategic reasons. Lucien Durosoir elaborates:

\footnotetext{
Anxious to maintain good relations with the military hierarchy, Caplet often works with a view to profitability: He composes, arranges, plays or transcribes in order to obtain a few days of permission, better conditions of accommodation or work. ${ }^{11}$
}

Post 1918, Caplet fully returned to composition. His health was weakened by exposure to gas during the war, and we can surmise that the exertion of undertaking frequent conducting engagements might have been too much of a challenge. The years 1919 to 1925 witnessed the creation of Cinq Ballades Française (Five French Ballads), La cloche fêlée and La mort des pauvres - two Baudelaire settings, Epiphanie-a fresque for cello and orchestra, and Le Miroir de Jesus for voice, chorus, string quartet and harp, to name just a few. Some of his larger-scale later works earnestly embraced themes of faith and religion at a time when it was still not fully fashionable to do so. Mélodies such as Les Prières and Prière Normande can be seen as precursors to some of these larger religious orchestral works.

Caplet's life was tragically cut short as he was entering his compositional prime. A simple cold caught on a train between Paris and Le Havre turned into pleurisy and his lungs, weakened by the war, failed. Caplet died on 22 April 1925, at the young age of forty-six.

\section{Détresse (Distress) 1915}

Détresse, composed in late 1915 for piano and voice, is a setting of a poem by Henriette Charsson. The stimulus for Charasson's poem is an account of a wounded soldier who went missing in action after the battle at Neuville St Waast en Artois on 28 September 1915. Caplet's mélodie

11 F. de Maindreville, S. Etcharry, op. cit., p. 99: "Soucieux de maintenir de bonnes relations avec la hiérarchie militaire, Caplet travaille souvent dans une optique de rentabilité: il compose, arrange, joue ou transcrit dans le but d'obtenir quelques jours de permission, de meilleurs conditions d'hébergement ou de travail." 
is significant, as it is the only work he would set to a text concerning a specific event in the war. Charasson's text evoked a war experience to which Caplet could relate on a personal level, as during his participation in the war it is likely that he witnessed many soldiers go missing in action. The other works Caplet set to poetry reflecting themes of war may be interpreted as his personal reflections and responses to the armed conflict. As Marie-Christine Catherine Allen explains:

\footnotetext{
This, along with the fact that [...it...] was written both during and about the war gives it a compelling sense of immediacy. The widely irregular metre and phrase lengths, and the lack of a rhyme scheme, create a spontaneous rhythm that defies any attempt at neatly packaging the chaos and horror of war. ${ }^{12}$
}

Charasson's text does not conform to a structured poetic form. It unfolds in a manner comparable to prose. And perhaps it is this proselike narrative that heightens the sense of intimacy as the poet appeals to God's mercy, as well as a sense of despair mingled with hope as it becomes clear towards the end of the poem that faith is the poet's solace. Allen further elaborates:

\footnotetext{
The length of "Détresse", its volatile and rich emotional life, and its irregular, imparisyllabic verse well-suited to the depiction of instability and anxiety, give it the character of a dramatic monologue. Set musically, it becomes a small scene with alternating recitative and arioso. ${ }^{13}$
}

Charasson's poem first outlines the sense of anguish and pain, beseeching God's mercy. We feel a strong sense of hopelessness as God is referred to as the "Eternal Hunter". But the poet's cognisance of mortality and relentless faith in God leads to the concluding thoughts that God can perform miracles and he is all encompassing. Faith is a powerful lifeline for the poet.

12 M.-C. C. Allen, The Wartime Melodies of Andre Caplet, PhD Thesis, University of Arizona, 1994, p. 101.

13 Ibid., p. 102. 


\section{The poem unfolds:}

Le main qui serre la coeur

s'est encore un peu refermée,

Et l'on étouffe dans le silence

en se regardant avec des yeux

agrandis,

tandis que les voix se taisent,

De peur d'entendre glisser les pas

feutrés de Celle...

qu'il ne faut point nommer.

Seigneur, de votre main trop lourde,

Vous pesez sur nos têtes,

N’appuyez pas si fort,

ou ma tête penchée sur ma poitrine

ne pourra plus se relever!

Seigneur, qu'est-ce qu'il faut que

l'on vous donne

pour que vous ayez pitié

et... que vous rendiez... votre proie,

O Terrible Chasseur Eternel

Qui me nez l'hallali

au son des canons formidables,

de des gueules de lourd métal?

Sa vie est dans vos mains,

et mon bonheur est dans vos mains,

et je sais qu'il me faut par vous

des miracles,

Il me faut des miracles,

et je vous les demande avec
The hand that presses the heart has tightened slightly, and we stifle in the silence as we look at each other with wide-open eyes,

and we hardly dare listen,

as the voices fall silent,

from fear of hearing the soft steps of Her...

who must not be named.

Lord, with your too heavy hand

You weight down our heads,

Press not too hard,

or my head bowed down over my breast

will no longer be able to rise!

Lord, what must we give you

For you to have pity

and... for you to give back... your prey,

Oh Awesome Eternal Hunter

You who sound the death flourish

with the terrible canon

and who makes your barking dogs out of these gaping jaws of ponderous metal?

His life is in your hands,

and my happiness is in your hands, and I know that I need miracles

from you,

I need miracles,

and I ask them of you with 


\begin{tabular}{c|c}
$\begin{array}{c}\text { la simplicité du désespoir, } \\
\text { vers la lune d'or pâles dans }\end{array}$ & $\begin{array}{c}\text { the simplicity of despair, } \\
\text { le ciel sombre, }\end{array}$ \\
$\begin{array}{c}\text { Quand ils croient encore que leur } \\
\text { père est tout puissant }\end{array}$ & $\begin{array}{c}\text { trembling hands towards } \\
\text { the moon of pale gold } \\
\text { et qu'il dispose du ciel. }{ }^{14}\end{array}$ \\
in the dark sky, \\
still believing that their father is all-powerful \\
and that he rules the heavens. ${ }^{15}$
\end{tabular}

Caplet's setting suggests a faithful musical interpretation of the poetic expression of despair, fear and hope in God. Détresse embodies a harmonic language that through its wealth of colour, tritone usage, extended tertian chordal structures, through-composed form, and recitative-like vocal line, fully reflects the anguished tone and prose-like nature of Charasson's poem. This discussion will highlight one compositional aspect that Caplet employs to musically reflect the theme of despair: the use of the locrian-natural-two and octatonic modes juxtaposed in the work as a harmonic reflection of the image of tension leading to anguish in the text.

The key signature of this work is D minor, and although the piece does not conform to standard tonal movement, the tonality does remain relatively functional through the retention of $\mathrm{D}$ minor as a tonal centre. The music is brought "home" to D minor in the final bars, and it is possible to interpret a perfect cadence in the final section. The juxtaposition of the locrian-natural-two and octatonic modes within the work might suggest that Caplet draws upon the half diminished sonorities of the locrian-natural-two as a stepping stone for creating a tonal shift from diatonic harmony to fully diminished harmony. Thus, this progression of half diminished to fully diminished modality could be regarded as a musical reflection of the tense feeling in the poem as it moves from a prickle of fear and apprehension to an unpreventable and threatening impression of doom. In Example 1, this may be observed as the vocal entry begins in bar 10:

14 H. Charasson, Détresse, in: A. Caplet, Détresse (score), Durand \& Cie., Paris 1918.

15 L. Pientre, A. Jacquon, André Caplet Mélodies, Timpani Records 2001, p. 18 (English translation in booklet by J. Drake). 


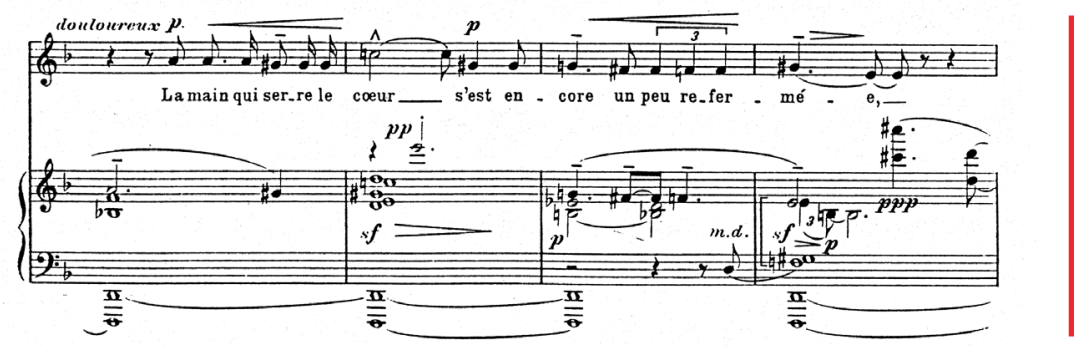

Ex. 1: A. Caplet, Détresse, bb. 10-13.

The text, "The hand that squeezes the heart has again tightened", suggests a painful situation becoming further distressing as painful pressure seizes the heart. The $p p$ chord over the word coeur ("heart") is outlined by the $\mathrm{D}$ locrian-natural-two, but upon moving to the end of the line as the poet describes the tightening sensation, the music transitions to D octatonic. Perhaps the $p p$ dynamic at the locriannatural-two point helps musically reflect the fragility of the heart, as the $s f$ dynamic over the octatonic chord reinforces the painful clutch. The fully diminished nature of the octatonic at this point serves as a musical affirmation of the ache the poet feels at this stage.

As the poem further unfolds, it speaks of the way in which voices fall silent in fear of oncoming hushed steps of her who must not be named. The music in this passage outlines the locrian-natural-two over the reference to "Her... who must not be named", and in the next line, as the poet speaks of the Lord's heavy hand upon their heads, Caplet moves to the octatonic mode. There are two images here: first, that of the fear associated with footsteps, and second, that of the weight of the pressing Lord's hand. As with the previous example, the half-diminished sonority of the locrian-natural-two mode musically illustrates a fearful moment which, when followed by a more anguished poetic image, develops into the fully diminished octatonic mode.

In Example 2, bar 25 outlines B locrian-natural-two and E flat locrian-natural-two. A D minor piano linking passage leads the music to $\mathrm{C}$ octatonic at bar 30 : 

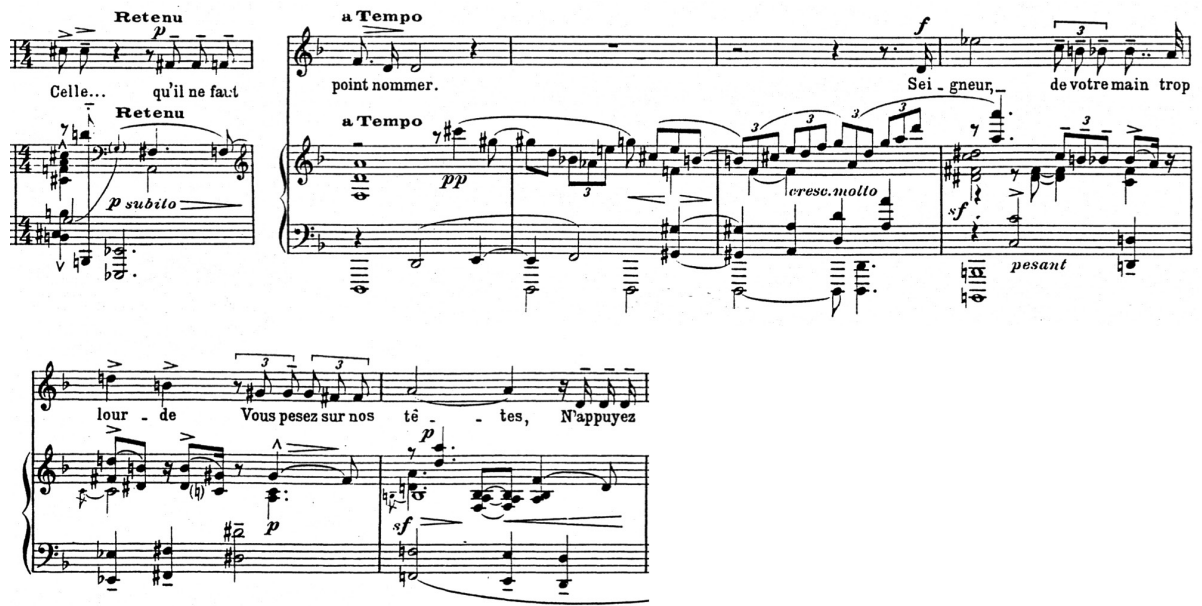

Ex. 2: A. Caplet, Détresse, bb. 25-31.

Further to the juxtaposing of the locrian-natural-two and octatonic modes, the use of the octatonic scale is so embedded into the fabric of this piece that it is possible to suggest a link between the root tones of the octatonic scales and the overall key of the song. The triad (including major and minor seventh) of this key is D minor: D F A C/C\#. Except for $\mathrm{A}$, Caplet uses each of these tones as root tone building blocks for the octatonic scale as it returns throughout the piece. The interpretation of the diminished nature of the octatonic scale as an essential component of the harmonic fabric aligns with the theme of anguish as an essential component at the core of the poem. Caplet's use of the octatonic mode musically represents his recognition of Charasson's literary intent, and this is heightened when juxtaposed with the halfdiminished form of the locrian-natural-two mode.

\section{Fôret (Forest) 1917}

By 1917, Caplet had experienced much action at the front. He was badly wounded twice, and we can only imagine the emotional impact the horrors of war had on the composer. Forret is the fourth and final mélodie of Le vieux coffret (The Old Chest), a set of poems by Remy de Gourmont. Pierre Bernac, student and faithful interpreter of the mélodies of Caplet, describes Fôret as: 
One of the most beautiful melodies of all the French concert repertoire: a perfect alloy of poem and music, the lyricism as well as the refinement of the music make its interpretation a delight for the performers. ${ }^{16}$

This is high praise, and perhaps in Forret we find an example of Caplet's lyricism and beauty in the interpretation of a text unrelated to the horrors of war. Perhaps the mystery, beauty, and serene nature of the forest was an escape for Caplet. In Forret, the poet addresses the forest directly, speaking of lovers who have passed through the trees, those who have sought shade and comfort of the leaves and mossy grass, and the kisses and passions that blossomed against the backdrop of the forest's green ferns. The poet's alexandrine verse structure accommodates a recurring invocation of the joy and gratitude the poet feels towards the forest. Caplet recognises the warmth and ardour in the poem, and his lyricism, flowing melodic line, instrumental-like piano parts, strophic setting, and rich tonal movement allow, as Joel Harder succinctly describes, "certain musical elements to establish a sense of recall, but also... musical ideas to develop organically." ${ }^{17}$ The poem follows:

Ô Forêt, toi qui vis passer bien des amants

Le long de tes sentiers, sous tes profonds feuillages,

Confidente des jeux, des cris, et des serment

Témoin à qui les âmes avouaient leurs orages.

Ô Forêt, souviens-toi de ceux qui sont venus

Un jour dété fouler tes mousses et tes herbes,

Car ils ont trouvé là des baisers ingénus

Couleur de feuilles, couleur d'écores, couleur de rêves.
Oh Forest, you who have seen many lovers pass by

Along your paths, under your heavy foliage,

The confidant of their games, their cries, and their pledges,

Witness to whom souls confessed their tempests.

Oh Forest, remember those who have come

On a summer's day treading your moss and grass,

For there they found innocent kisses

The colour of leaves, the colour of bark, the colour of dreams.

16 P. Bernac, The Interpretation of French Song, London 1970, p. 226.

17 J. Harder, op. cit., p. 86. 
Ô Forêt, tu fus bonne, en laissant le désir

Fleurir, ardente fleur, au sein de ta verdure.

Lombre devint plus fraîche: un frisson de plaisir

Enchanta les deux coeurs et toute la nature.

Ô Forêt, souviens-toi de ceux qui sont venus

Un jour d'été fouler tes herbes solitaires

Et contempler, distraits, tes arbres ingénus

Et le pâle océan de tes vertes fougères. ${ }^{18}$
Oh Forest, it was good of you to let desire

Bloom, an ardent flower, within your greenery.

The shadow becomes more fresh; a thrill of pleasure

Enchanted the two hearts and all nature.

Oh Forest, remember those who came

On a summer's day treading your lonely grass

And meditating, plunged in thought, on the innocent trees

And the pale ocean of your green ferns. ${ }^{19}$

Since an in-depth discussion of the full compositional processes at play in this work surpass the boundaries of this article, it will consider only a few instances of Caplet's treatment of the acoustic scale in Fôret. The acoustic scale, or lydian-dominant, is an interesting mode. It can be interpreted as a superimposition of the lydian and myxolydian modes, and the resulting harmonies of the scale evoke a wider range of chordal structures due to the extensions of the sharpened fourth and flattened seventh within the scale. Historically, as can be seen in work of Debussy, this scale has been used as a modulatory device. For example, Dimitri Tymoczko's discussion of Des pas sur le neige draws attention to the acoustic scale as a characteristic modulatory device by Debussy.

The transition back to D natural minor [in Des pas sur le neige] illustrates one of Debussy's characteristic modulatory devices, the use of an acoustic scale as an intermediary between the whole-tone and diatonic collections. ${ }^{20}$

18 R. de Gourmont, Fôret, in: A. Caplet, Quatre Poèmes de Rémy de Gourmont "Le vieux coffret" (score), Durand \& Cie., Paris 1918.

19 L. Pientre, A. Jacquon, op. cit., p. 17 (English translation in booklet by J. Drake).

20 D. Tymoczko, A Geometry of Music: Harmony and Counterpoint in the Extended Common Practice, New York 2011, p. 322. 
Caplet's use of the acoustic scale is different, because it does not appear to function as a modulatory technique. In Fôret, the mode occurs several times, usually in a chordal texture that recalls the opening motif.

Example 3 demonstrates this chordal motif:

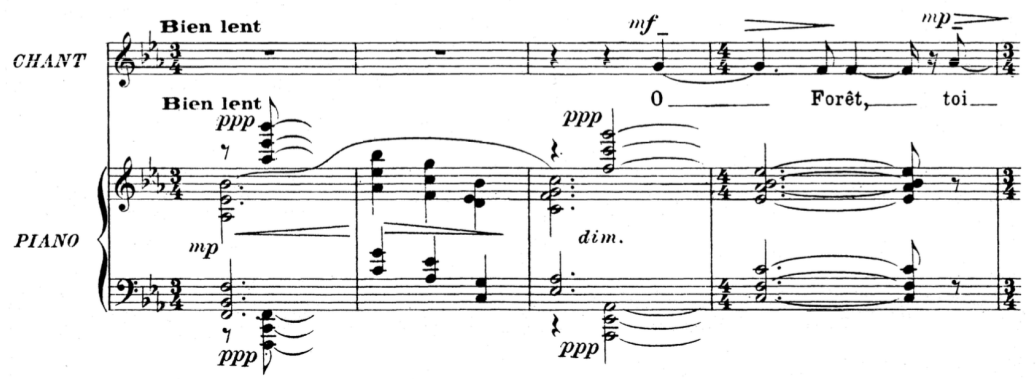

Ex. 3: A. Caplet, Fôret, bb. 1-3.

The acoustic scale appears frequently throughout the setting of the first stanza of the poem. In this stanza, the poet addresses the forest directly, speaking of lovers who pass through the forest and their confident games throughout the leafy foliage, then ends the stanza with a reference to those who have confessed their passions to the forest. The primary imagery is that of the lovers in the forest. Caplet evokes the sense of space created by a tall canopy of trees through the wide-ranging, stately chordal introduction, and throughout this first stanza, the acoustic scale appears connected to incarnations of this opening chordal motif. Interpreting the precise reason Caplet uses the acoustic scale at these chordal points is difficult. But considering the text's description of lovers coming together in the forest, it is feasible to suggest that the nature of the acoustic scale's construction-two modes superimposed that create a new set of harmonic possibilities-could represent the two lovers. This interpretation, combined with the shape of the chordal structure, outlines and reaffirms the lovers situated in the forest.

Throughout bars 8-11 in Example 4, the music passes through $\mathrm{D} b$ acoustic moving to $\mathrm{E} b$ acoustic. This harmonic movement appears in conjunction with the chordal texture recalling the opening, and the poetic text at this point describes the confident games the lovers play in the forest. 


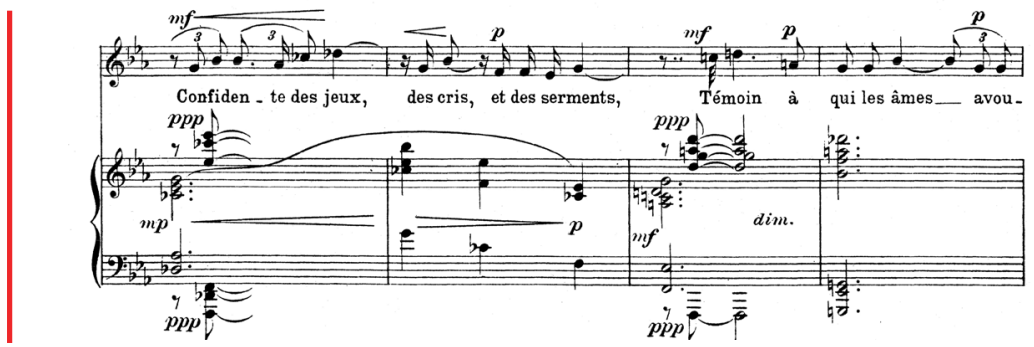

Ex. 4: A. Caplet, Fôret, bb. 8-11.

The use of the acoustic scale as harmonically and texturally representing the forest could be further affirmed in bar 30, where the poet addresses the forest directly once more. The wide-ranging chordal texture appears as the poet mentions the word "forest", and the $\mathrm{Db}$ acoustic scale returns at this precise point.

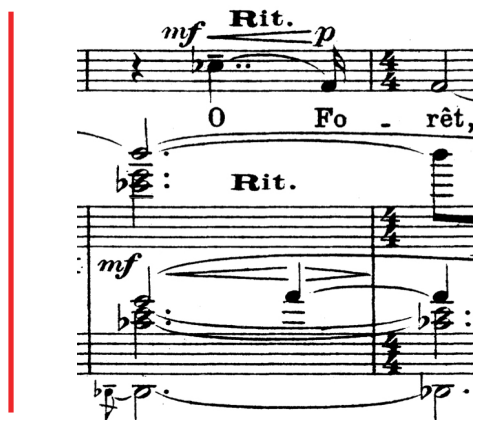

Ex. 5: A. Caplet, Fôret, b. 30.

Throughout the mélodie, Caplet's use of the modally-superimposed nature of the acoustic scale can be interpreted as a means to identify the two lovers in the forest. He then further uses this tonality in combination with texture in the music that evokes the breadth of the forest. This use of the acoustic scale might suggest that rather than using it either as a functional tonal building block in the harmonic language or modulatory technique, Caplet observed the nature of the scale's construction, and chose to use this as a colouristic device to enhance his interpretation of the imagery in the poem. 


\section{Écoute (Listen) 1924}

In the years following the First World War, Caplet found himself back in Paris actively composing and immersing himself into the musical culture there. His interest in the promotion of music from outside France was strong, and along with Ravel, Dukas, Roussel, Messager and Roland-Manuel, Caplet was involved in the penning of a strong letter to Le courier musical in response to the ongoing dispute between Jean Wéiner and Louis Vuillemin. Weiner had promoted a concert featuring Schoenberg's Pierrot Lunaire, but Vuillemin publicly resisted this, calling it an "invasion of foreign and Jewish music in France." 21 Caplet was fully supportive of the promotion of foreign modern music in French society and he was happy to sign his name to the letter to Le courier musicale, an extract of which follows:

\footnotetext{
They affirm their delight of having been able to hear Arnold Schoenberg's Pierrot Lunaire, thanks to Monsieur Jean Wéiner, as well as a series of new works, French and foreign, whose tendencies are open to discussion, but whose interest is certainly not. They would like to take this occasion to express the hope that patriotism err a bit less in an area where it has nothing to gain, but everything to lose. ${ }^{22}$
}

Actions such as this reveal that Caplet's attitudes and standing within musical society were highly receptive to creativity and new ways of interpretation. He possessed a strong openness to music from outside France, and was interested in the musical world around him.

Caplet's approach to musical composition around this time reflected this openness. Écoute, composed just one year before his premature death, is a setting for voice and flute rather than, like the previous examples, voice and piano. This piece is significant in that the harmonic language features a progressive mixing of synthetic scales with standard modal and tonal practice. The inspiration for this work is a poem by Rabindranath Tagore which describes a flute singing a melody evocative of wildflowers and water. The poem is brief but fully evokes imagery of nature and song:

21 B. L. Kelly, op. cit., p. 73.

22 A. Orenstein (ed.), A Ravel Reader: Correspondence, Articles, Interviews, New York 1990, p. 240. 


Écoute, mon coeur,
dans cette flûte chante
la musique du parfum
des fleurs sauvages,
des feuilles étincelantes et
de l'eau qui brille;
la musique d'ombres sonores,
d'un bruit d'ailes et d'abeilles.
La flûte a ravi son sourire
des lèvres de mon ami
et le répand sur ma vie. ${ }^{23}$

\author{
Listen, heart of mine, \\ in this flute sings \\ the perfumed music of \\ wild flowers, \\ of shimmering leaves and of \\ shining water; \\ the music of shadows, \\ of the sounds of wings and of bees. \\ The flute has stolen its smile from \\ the lips of my friend \\ and pours it over my life. ${ }^{24}$
}

The poetic imagery is reminiscent of nature, and Caplet's flute line in Écoute thoroughly embraces this. The flute part is full of runs, tremolos, trills and grace-notes as it describes the water, flowers, and bees portrayed in the poem. The vocal line provides a contrast to the vivid and lively nature of the flute, as longer and more sustained lines with a serene nature establish the perfect balance for the dual nature of the work. The poem is free from the restrictions of regular metre and rhythms, and this structural aspect is reflected by the freely unfolding, almost improvisatory character in Caplet's musical setting.

Écoute is infused with modal and synthetic colour, including dorian, phrygian, and lydian modes, octatonic scales, as well as palindromic patterns and chromatic patterns. Caplet uses these modes and experimental patterns as a means of describing the sounds of nature in the poem. For example, in bars 50-59 in Example 6, the poet speaks of the music of shadows, clouds, wings, and bees. The vocal line can be interpreted as an E phrygian scalar pattern. But simultaneously contrasting this pattern, the flute line moves in chromatic demisemiquaver patterns suggestive of the shadows, that, when connected by two sharp staccato demisemiquavers, transforms into a tremolo chromatic scalar pattern. The simultaneous use of the chromatic line in the flute with the E phrygian scale in the vocal line could also be interpreted as an example of polytonality.

23 R. Tagore, Écoute (French translation by H. du Pasquier), in: A. Caplet, Écoute, mon coeur (score), Durand \& Cie., Paris 1925.

24 L. Pientre, A. Jacquon, op. cit., p. 19 (English translation in booklet by J. Drake). 

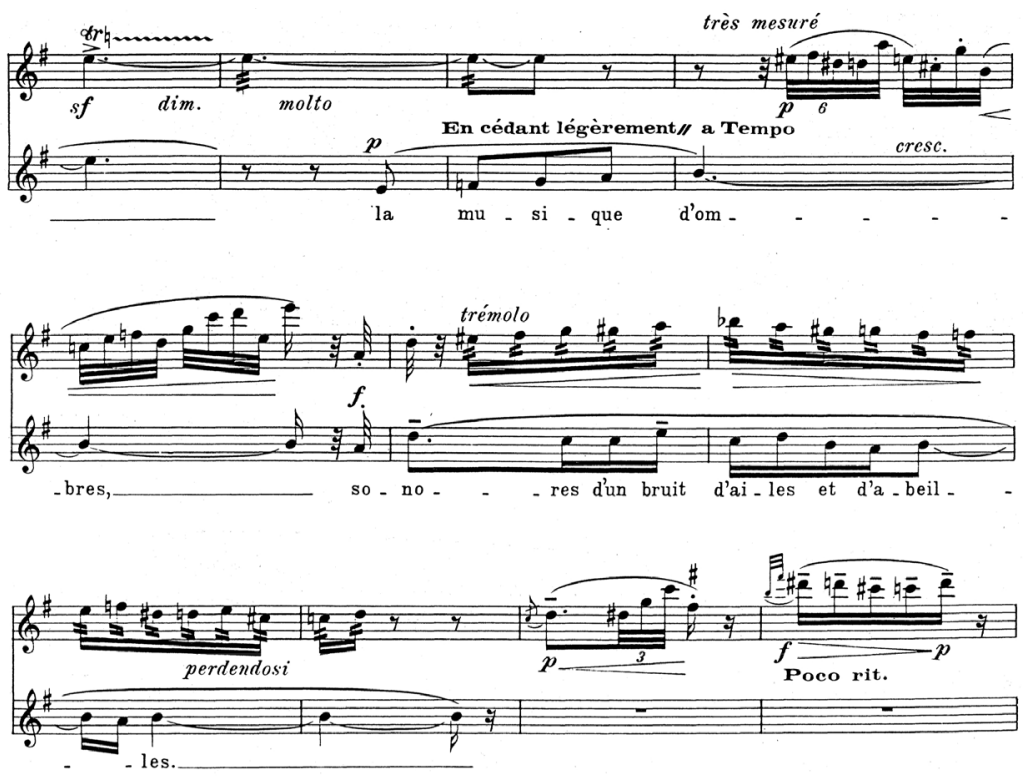

Ex. 6: A. Caplet, Écoute, bb. 50-59.

Écoute allows the virtuosic quality of the flute to be fully explored. There are passages where the flute is unaccompanied by the voice, allowing a full evocation of the sights and sounds of nature. For example, in the flute solo in bars 20-31, there are three collections, stating three different textures through which the music passes. As Example 7 shows below, the first collection (bars 20 -22) is almost whole tone except for the Ft. Then there is a chromatic pattern in bars 24-25, after which an $\mathrm{E}$ trill leads the music to an E phrygian collection beginning at bar 26 . The textures of these collections could represent the swirl of the wind through the whole tone flourish, the buzzing of the bees through the sharply chromatic staccato and trill textures, and the gentle song of the wildflowers through the flowing E phrygian scale. 

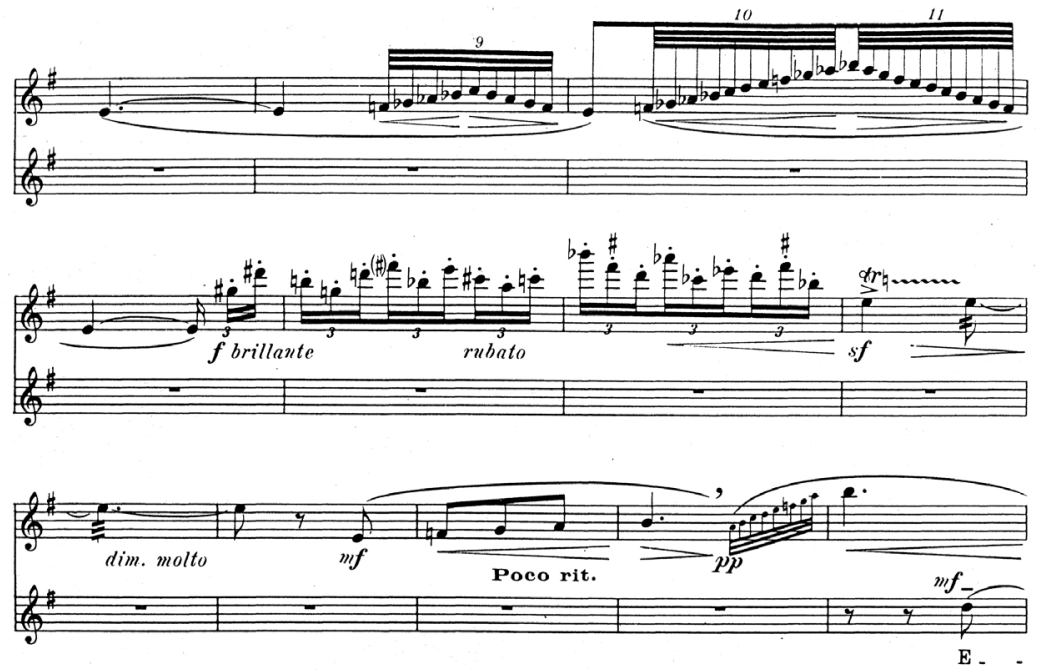

Ex. 7: A. Caplet, Écoute, bb. 20-31.

In her discussion of Caplet's prominence, Sanaé Kanda remarks that:

The shadow of Fauré, Duparc, Hahan, and most particularly Debussy and Ravel, kept Caplet in the background for much of his tragically short life. His role as conductor, orchestrator and facilitator for these very people occupied enough of his time to interfere with the propagation of his own music. ${ }^{25}$

Despite a small compositional output and relatively modest posthumous musical fame and renown, however, Caplet's harmonic experimentation reveals that he was forging a compositional voice of his own. His individual and distinct harmonic language can be interpreted, especially as it evolved in mature works such as Écoute, as a foreshadowing of the inventive language of Messiaen, in religious themes, modality, and synthetic scalar contexts.

This article has presented a small snapshot of some of the devices which Caplet employs to saturate his harmonic language with modal colour and texture. His mélodies display a richness of harmonic language, which through the processes of compositional inventiveness and experimentation offer a valuable contribution to the genre of the

25 S. Kanda, The Role of the Piano in the Mélodie of André Caplet, $\mathrm{PhD}$ Thesis, Boston University, 2002. 
French mélodie. Détresse, Fôret, and Écoute demonstrate some of the different ways in which Caplet employs modality, often non-functional and coloristic, to describe and interpret poetic themes and imagery. His use of such harmonic devices as juxtaposing half-diminished and diminished modes to paint a harmonic portrait of despair and anguish, using modally superimposed constructs to illustrate the marriage of musical texture and poetic subjects, and even embracing an interweaving of whole tone and chromatic tonalities with modality to describe pictures and reflections of nature, demonstrate that he was a significant figure of early French musical modernism whose harmonic language evolved and became more modally experimental as he matured. And exploring Caplet's compositional voice helps illuminate the compositional tendencies, thought processes, and artistic reactions of active musicians to the social, cultural and artistic trends in the tightly woven musical fabric of Third Republic France.

\section{Abstract}

André Caplet is a noteworthy figure in the early years of the 2oth century French music. A founding member of the Société Musicale Indépendante and advocate of new contemporary music, Caplet is also remembered for his contributions to Debussy's Le Martyre de Saint-Sébastien and La boîte à joujoux.

Caplet's musical output from the years pertaining to the Great War and beyond demonstrates a colourful harmonic language. This authentic harmonic language presents itself as a highly complex and sophisticated interweaving of modality and diatonicism, and there are numerous instances of progressive use of modal structures within these mélodies.

This article presents a reflection upon some of the developments within Caplet's exploration of tonality through the lens of selected works, from 1914 to his death in 1925. Supporting examples of Caplet's distinctive approach to the fusion of diatonicism and modality, and the usage of synthetic scale structures will be considered.

Caplet's inventive harmonic language offers much richness in terms of creativity and imagination. He was a composer who favoured different musical processes and conventions. Exploring his compositional approach will help illuminate André Caplet's individual harmonic language, and place within the field of French musical modernism. 


\section{Keywords}

André Caplet, twentieth-century French music, analysis, music theory, modality, harmonic language

\section{Abstrakt}

Perspektywa analityczna ewolucji harmonicznej André Capleta na wybranych Mélodies, 1915-1925

André Caplet jest ważną postacią muzyki francuskiej początku XX wieku. Był założycielem Société Musicale Indépendante i orędownikiem muzyki nowej. Został zapamiętany także dzięki swojemu wkładowi w powstanie Le Martyre de Saint-Sébastien i La boîte à joujoux Claude’a Debussy'ego.

Cechą charakterystyczną dorobku twórczego Capleta z lat poprzedzających I wojnę światową i późniejszych jest bogaty język harmoniczny, będący mieszanką harmoniki modalnej i diatoniki, przeplatających się w wyszukany i skomplikowany sposób. Także w Mélodies można odnaleźć wiele przykładów nowatorskiego użycia struktur modalnych.

Niniejszy artykuł jest refleksją nad niektórymi z odkryć na polu tonalności dokonanych przez Capleta w jego wybranych dziełach $z$ lat 1914-1925. Przedstawiono także przykłady innowatorskiego podejścia Capleta do łączenia modalizmów z diatonizmami, zwracając uwagę na użycie struktur powstałych w wyniku ich syntezy.

Nowoczesny język harmoniczny Capleta oferuje bogactwo rozwiązań na polu kreatywności i wyobraźni muzycznej. Był to kompozytor, który używał różnych konwencji i technik kompozytorskich. Analiza jego warsztatu pomoże zrozumieć indywidualny język harmoniczny André Capleta i umieścić go w kręgu francuskiego modernizmu.

\section{Słowa kluczowe}

André Caplet, muzyka XX wieku we Francji, analiza, teoria muzyki, modalność, harmonika, język muzyczny 


\section{Bibliography}

Allen M.-C. C., The Wartime Melodies of Andre Caplet, PhD Thesis, University of Arizona, 1994.

Bernac P., The Interpretation of French Song, London 1970.

Harder J., The Mélodies of André Caplet: A Guide to Performance, DMA Thesis, The Juilliard School, 2015.

Huneau D., André Caplet (1878-1925) Debussyste indépendant, Weinsberg 2007.

Kanda S., The Role of the Piano in the Mélodie of André Caplet, $\mathrm{PhD}$ Thesis, Boston University, 2002.

Kelly B., Music and Ultra Modernism in France: A Fragile Consensus, 1913-1939, Woodbridge 2013.

Maindreville F de., Etcharry S., La Grande Guerre en musique: vie et creation musicales en France pendant la Première Guerre mondiale, Bruxelles 2014.

Orenstein A., (ed.), A Ravel Reader: Correspondence, Articles, Interviews, New York 1990.

Spencer W., André Caplet, Aussi Musicien Français, "Revue Bege de Musicologie" 1982-84, 36(38).

Spencer W., The Relationship between André Caplet and Claude Debussy, "The Musical Quarterly" 1980, 66(1).

Toff N., Monarch of the Flute, Oxford 2005.

Tymoczko D., A Geometry of Music: Harmony and Counterpoint in the Extended Common Practice, New York 2011.

Poems and translations:

Charasson H., Détresse, in: Caplet A., Détresse (score), Durand \& Cie., Paris 1918.

Gourmont R. de, Fôret, in: Caplet A., Quatre Poèmes de Rémy de Gourmont "Le vieux coffret" (score), Durand \& Cie., Paris 1918.

Pientre L., Jacquon A., André Caplet Mélodies, Timpani Records 2001 (English translation in booklet by J. Drake).

Tagore R., Écoute (French translation by H. du Pasquier), in: Caplet A., Écoute, mon coeur (score), Durand \& Cie., Paris 1925. 